\title{
ІНФОРМАЦЙНІ ТЕХНОЛОГІЇ В ОСВІТІ СТУДЕНТІВ-МЕДИКІВ У ЛЬВІВСЬКОМУ НАЦІОНАЛЬНОМУ МЕДИЧНОМУ УНІВЕРСИТЕТІ ІМЕНІ ДАНИЛА ГАЛИЦЬКОГО
}

\author{
С. В. Різничок
}

Львівський національниймедичний університет імені Данила Галиџького

\section{INFORMATION TECHNOLOGIES IN EDUCATION OF MEDICAL STUDENTS IN LVIV NATIONAL MEDICAL UNIVERSITY BY DANYLO HALYTSKY}

\author{
S. V. Riznychok
}

\author{
Lviv National Medical University by Danylo Halytsky
}

\begin{abstract}
Інформаційні технології (IT) накладають все більший вплив на медичну освіту та практику. У 2014/2015 н. р. на кафедрі медичної інформатики Львівського національного медичного університету імені Данила Галицького серед студентів медичного і стоматологічного факультетів та лікарів-інтернів було проведено опитування, метою якого було визначити, як вони суб' єктивно оцінюють свою кваліфікацію у використанні комп'ютерів та володіють знаннями про IT. Дослідження проводилося добровільно за анонімним анкетуванням, що складалося з 22 питань, розділених на п'ять категорій, які містять відомості про студента/лікаря-інтерна: стать, вік, рік навчання, комп'ютерні навички, використання Інтернет, методи отримання інформації для навчання в даний час і рекомендації щодо поліпшення викладання IT. Виявлено, що студенти, які навчаються за кредитно-модульною системою, суттєво відрізняються за рівнем знань, цілями використання та практичного застосування IT-знань від осіб, які навчалися за традиційною системою. Водночас рівень їхніх знань, у цілому, відповідає рівню знань ІТ студентів-медиків Університету Сараєво в Боснії і Герцоговині, так само як і Медичного університету міста Рієка в Хорватії.
\end{abstract}

Information technology (IT) imposes increasing influence on medical education and practice. In the 2014/2015 academic year at the Department of Medical Informatics of Lviv National Medical University by Danylo Halytsky, students of medical and dental faculties and doctor-interns were subjected to examination which aim was to determine how they subjectively evaluate their skills to use computers and have knowledge of IT. The study was conducted on a voluntary anonymous survey that consisted of 22 questions divided into five categories that contain information about the student / intern-doctor: age, year of study, computer skills, Internet use, methods of obtaining information for training at the concrete moment and tips to enhance teaching IT. It was found that students who study credit system, differ significantly in terms of knowledge, aims of theoretical and practical application of IT knowledge from those who have studied the traditional system. However, the level of their knowledge, in general, is such as the level of knowledge of IT medical students of the University of Sarajevo in Bosnia and Herzegovina, as well as the Medical University of Rijeka in Croatia.

Вступ. Двадцяте століття характеризується революційним розвитком інформатики. Нині, в ХХІ столітті інформаційні технології і комп'ютери є невід'ємною частиною будь-якої сфери людського життя, особливо освіти та розвитку комунікацій. IT принесли суттєві зміни у медичну освіту і практику, особливо в галузі діагностики. Приєднання України у 2005 р. до Болонського процесу, сучасні євроінтеграційні процеси в науковій та освітній сферах спонукають до підвищення стандартів вищої медичної освіти в Україні.

На важливість впровадження IT у систему охорони здоров'я України звертали увагу багато фахівців медицини. О. Ю. Майоров, В. М. Пономаренко,

(C) С. В. Різничок
М. І. Хвістюк та В. В. Кальниш всесторонньо розглянули проблеми та перспективи впровадження інформаційних технологій у системі охорони здоров'я та медичної освіти [1], В. О. Качмар дав оцінку загального стану розвитку медичної інформатики в Україні [2]. Проблеми підготовки з медичної інформатики студентів вищих навчальних закладів проаналізували Ю. О. Іщейкіна та О. В. Сілкова [3].

Основна частина. Метою цього дослідження $\epsilon$ визначити, як студенти-медики талікарі-інтерни суб' єктивно оцінюють свої навички використання комп'ютерів, i отримати рекомендації для вдосконалення викладання медичної інформатики у Львівському національному медичному університеті імені Данила Галицького. 
У 2014/2015 навчальному році на кафедрі медичної інформатики Львівського національного медичного університету імені Данила Галицького було проведене наглядове, аналітичне дослідження. У дослідження були включені 75 осіб, з них 26 студентів медичного, 28 сту- дентів стоматологічного факультетів і 21 лікар-інтерн. Опитування проводилося добровільно за анонімним анкетуванням. Для складання анкети було використано досвід дослідження, проведеного на медичному факультеті Університету Сараєво з Боснії і Герцоговини [4].

\begin{tabular}{|c|c|c|c|c|}
\hline \multicolumn{5}{|c|}{ І.ЗАГАЛЬН -ВIДОМОСТІ-ПIРО РЕСПОНДЕНТА } \\
\hline fanyдbreng & \multicolumn{3}{|c|}{ 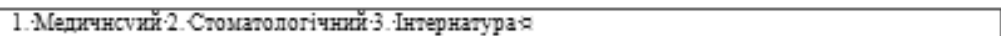 } & द्र \\
\hline Pixнавчання & \multicolumn{3}{|c|}{ 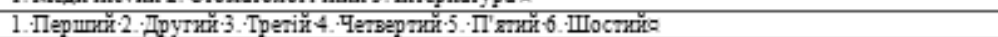 } & g \\
\hline Piкнародаенняя & \multicolumn{3}{|r|}{ 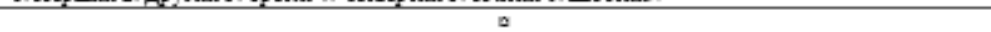 } & g \\
\hline Cramba & \multicolumn{3}{|c|}{ 1. पодовіча:2. Жіночая } & g \\
\hline \multicolumn{5}{|c|}{ 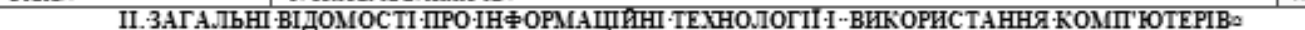 } \\
\hline \multirow{2}{*}{\multicolumn{3}{|c|}{ 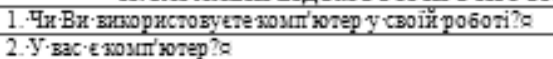 }} & 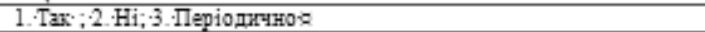 & g \\
\hline & & & 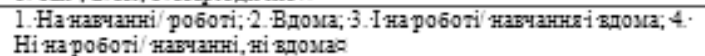 & द्र \\
\hline \multicolumn{3}{|c|}{ 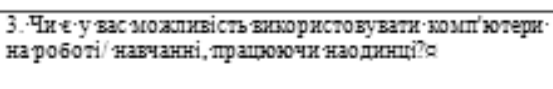 } & 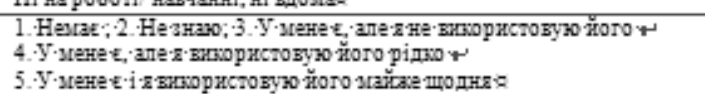 & द्र \\
\hline \multirow{4}{*}{\multicolumn{3}{|c|}{ 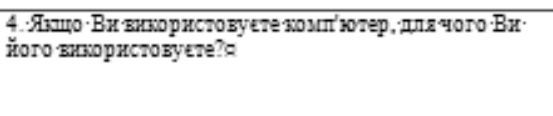 }} & \multirow{4}{*}{ 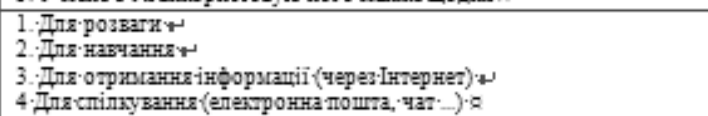 } & द्र \\
\hline & & & & $g$ \\
\hline & & & & द्र \\
\hline & & & & g \\
\hline \multirow{5}{*}{\multicolumn{3}{|c|}{ 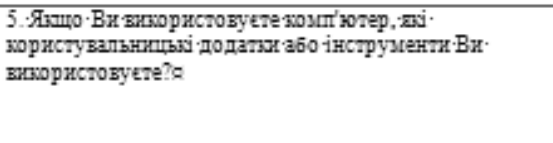 }} & \multirow{5}{*}{ 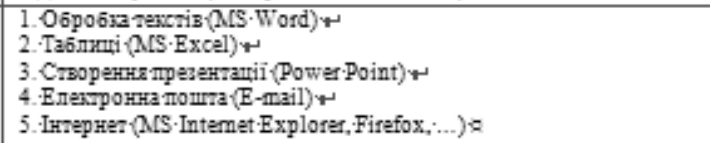 } & द \\
\hline & & & & g \\
\hline & & & & a \\
\hline & & & & a \\
\hline & & & & ga \\
\hline \multirow{5}{*}{\multicolumn{3}{|c|}{ 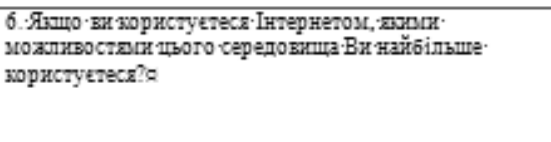 }} & \multirow{5}{*}{ 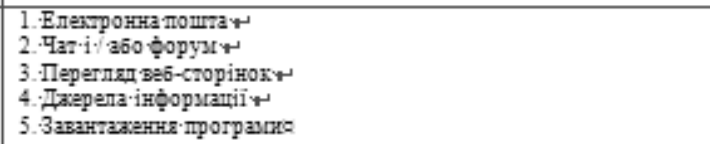 } & g \\
\hline & & & & a \\
\hline & & & & द्र \\
\hline & & & & g \\
\hline & & & & व \\
\hline \multicolumn{3}{|c|}{ 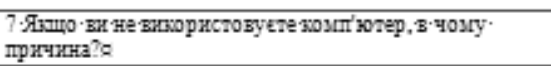 } & 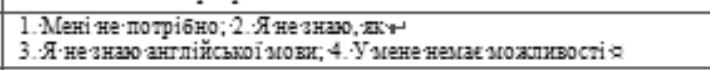 & द्र \\
\hline \multicolumn{3}{|c|}{ 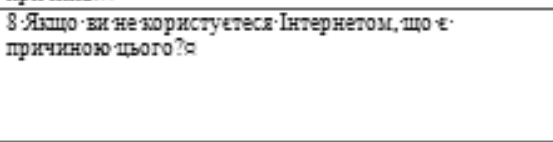 } & \multirow[t]{2}{*}{ 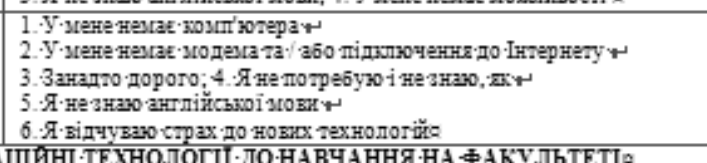 } & a \\
\hline \multicolumn{4}{|c|}{ 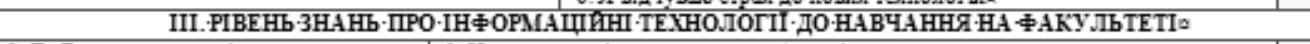 } & \\
\hline 9.Де·Вн набудин & 8706074.9. & 1. Hearano & 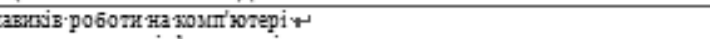 & g \\
\hline wos!r' wrepi? & (1) & 2. Під भас & 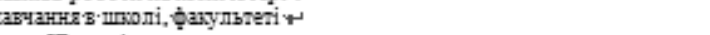 & a \\
\hline & & 3. Відзідуз & 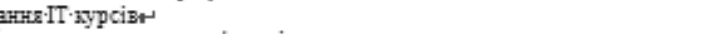 & a \\
\hline & & 4. Cavocri & 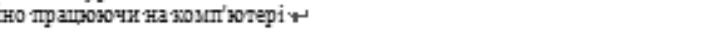 & a \\
\hline & & 5.Xrocb H: & & a \\
\hline 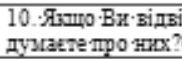 & ypcr, m110 an: & $\begin{array}{l}\text { 1. R.невід } \\
\text { 3. Bониза }\end{array}$ & 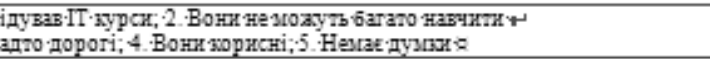 & a \\
\hline 11. Axuro Brine & ขacti B.T. & 1. Недоста & Hzінформантіz тро аурст & द्र \\
\hline зурсах, причинок & & 2. Bapricrs & аурсів & g \\
\hline & & 3. Відсугн & 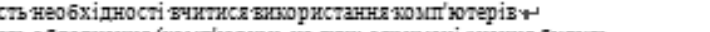 & द्र \\
\hline & & 4. Відсугт & 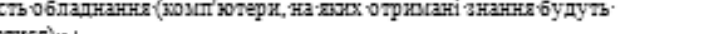 & a \\
\hline & & $\begin{array}{l}\text { 3acrocosys } \\
5 \cdot \text { Hasmor }\end{array}$ & 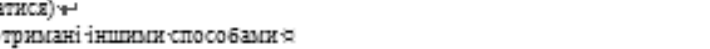 & g \\
\hline & PKMAHI $3 \mathrm{H}$ & IH马·3·IHథ & PМАЦИНИХ-ТЕХНРОЛОГТИ-ВИКОРИСТОВУТЬСЯ॰ & \\
\hline 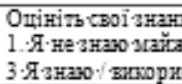 & 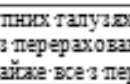 & 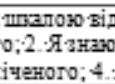 & 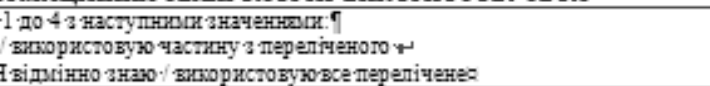 & \\
\hline 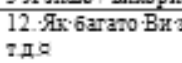 & sosir' sorept & ладові, тaxi & 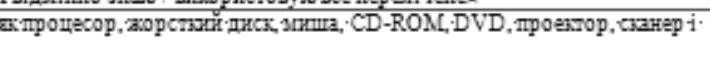 & a \\
\hline 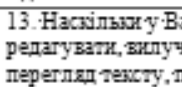 & 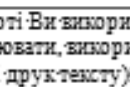 & osyene.Word & 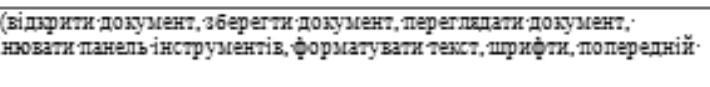 & व्र \\
\hline 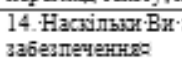 & 7asong repu & or, ax & 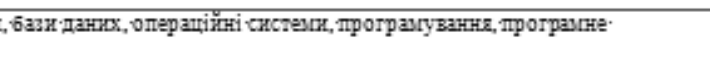 & a \\
\hline 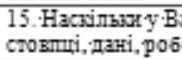 & 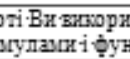 & $\begin{array}{l}\text { syere:Excel } \\
\text { iant, crpope }\end{array}$ & 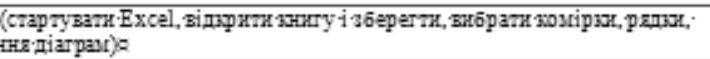 & g \\
\hline 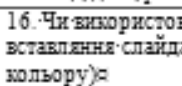 & 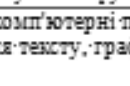 & 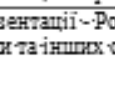 & 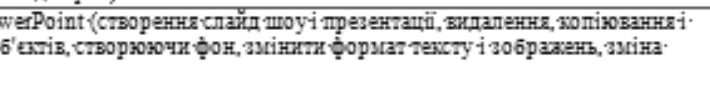 & a \\
\hline 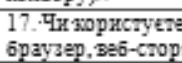 & $\begin{array}{l}\text { ннетом (miд } \\
\text { посиланнд, }\end{array}$ & 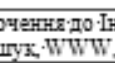 & 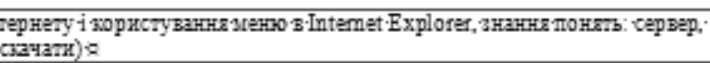 & 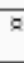 \\
\hline & V.MAGEYT & HABपAH & 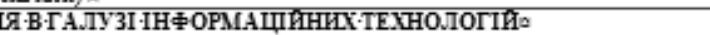 & \\
\hline 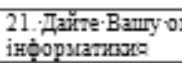 & сті виладанн & a. zą̧enpias & 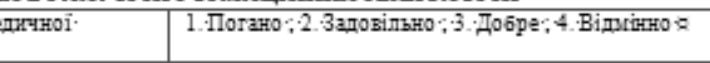 & a \\
\hline
\end{tabular}

Рис. 1. Анкета для студентів/ інтернів /випускників медичного та стоматологічного факультетів з використання та знання інформаційних технологій. 
Анкета (рис. 1) включала 22 запитання, розділені на п'ять категорій, які містять інформацію про студентів: стать, вік, рік вступу, комп'ютерні навички, відомості про інформаційні технології до навчання на факультеті, спосіб отримання в даний час знань та рекомендації тестованих для того, щоб поліпшити своє IT-навчання. Респонденти оцінювали свої знання за шкалою від 1 до 4, де 1 відповідає найнижчому (я не знаю майже нічого з переліченого) і 4 - найвищому (я відмінно знаю і використовую все перелічене) рівню. Відмінності у статі, віку і системах навчання були важливими для результатів дослідження, враховуючи той факт, що у відібраних для дослідження групах застосовувалися різні методики для вивчення медичної інформатики.

Усі 75 осіб, які взяли участь в анкетуванні, були розділені на дві групи, одна 3 них - студенти медичного та стоматологічного факультетів (72 \%), які навчаються за кредитно-модульною системою і складають групу А, інша - лікарі-інтерни (28 \%), які навчалися за традиційною системою - групу Б. Жіноча частина респондентів складає $66,7 \%$, чоловіча 33,3 \%. Середній вік усіх тестованих студентів 19,95, групи А - 18,5, групи Б - 23,67. Різниця у частоті використання комп'ютерів студентами різних груп показана на рисунку 2.

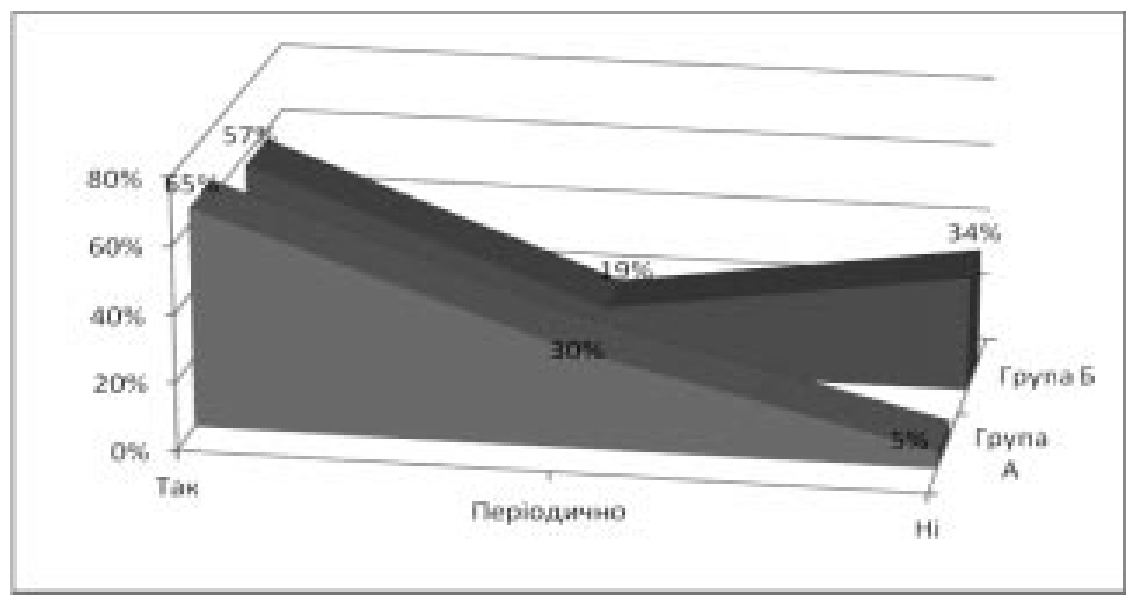

Рис. 2. Частота використання комп'ютерів.

Переважна більшість респондентів має комп'ютери вдома: 98 \% групи А, з них 33 \% мають можливість використовувати комп'ютер упродовж всього дня - і на навчанні, і вдома; 71,4% осіб групи Б.

Для визначення мети використання комп'ютерів було запропоновано чотири варіанти відповіді: 1 - для розваги, 2 - для навчання, 3 - для отримання інформації (через Інтернет), 4 - для спілкування (електронна пошта, чат,... ). Опитування показало, що досліджувані групи суттєво відрізняються за метою використання комп'ютерів (рис. 3). Так, 67 \% осіб групи А використовують комп'ютери для всіх перелічених пунктів (розваги, навчання, отримання інформації та спілкування), і жоден з них не використовує комп'ютер лише для розваги або спілкування, тоді як лише для розваги комп'ютери використовують $19 \%$ осіб групи Б і лише для отримання інформації-33 \% 3 них.

За знанням користувацьких додатків та практичними навиками у їх використанні видно, що близько половини осіб (52,5%), які навчалися за традиційною системою, користуються лише інтернет-браузерами (група Б), а всіма прикладними програмами -
14,3 \%. У той час як студенти-медики (група А), які використовують лише інтернет-браузери та е-пошту, складають 20,4 \% та активно застосовують програму із створення презентації- більше 50 \%, що удвічі більше, ніж у групі Б (рис. 4).

Дослідження показало, що ніхто з обох груп не навчався на IT-курсах і причини цього є приблизно однакові для обох груп: отримання навиків іншими способами (група А - 43 \%, група Б - 38 \%), відсутність необхідності покращити свої знання про використання комп'ютера (група А - 31 \%, група Б - 29 \%) та недостатня інформація про курси (група А - 17 \%, група Б - 10 \%). Вартість курсів була вирішальною лише для 4-5 \%. 61,9\% \% осіб групи Б відповіли, що досягли вміння користуватися комп'ютером навчаючись самостійно, у групі А цей показник складає 35 \% і 31 \% осіб цієї групи здобули навики у поєднанні формальної освіти та самостійного навчання.

У таблиці 1 наведені пропозиції щодо поліпшення освіти в області IT. Слід відзначити, що респонденти групи Б виділили важливим більше навчання через Інтернет та удосконалення дистанційної форми на- 


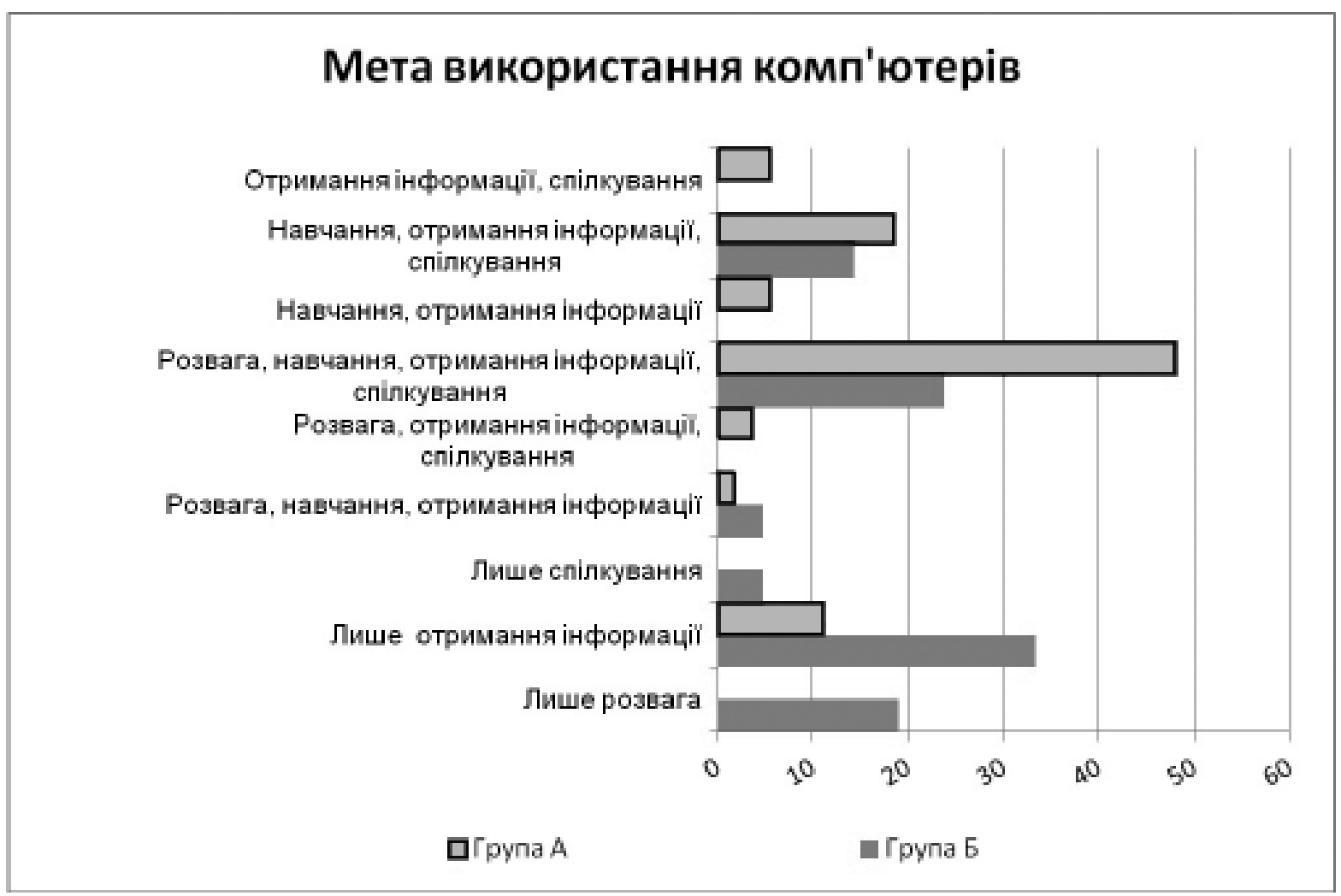

Рис. 3. Різниця в цілях використання комп’ютерів.

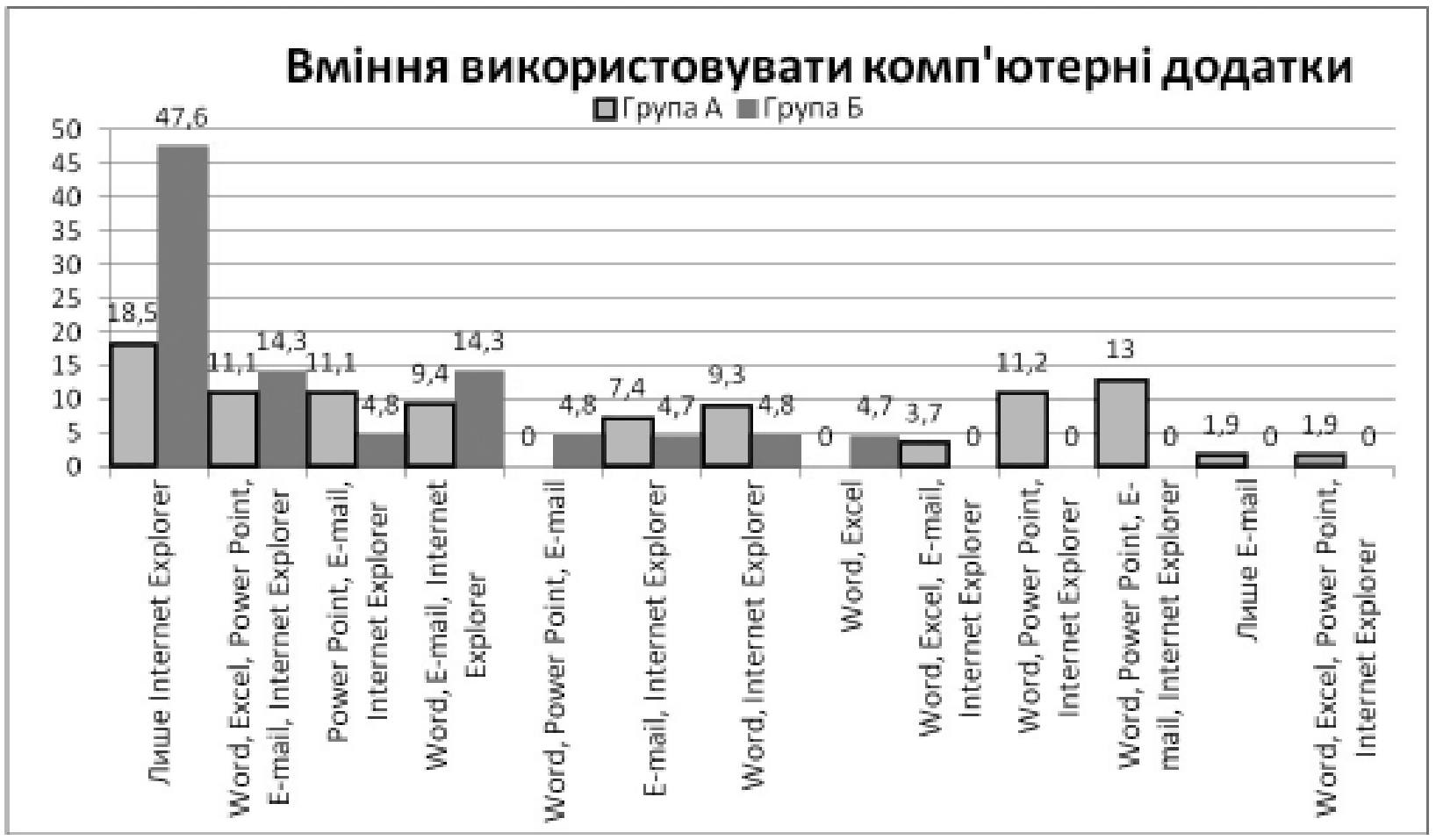

Рис. 4. Вміння застосовувати користувальницькі додатки і комп’ютерні інструменти (у \%).

вчання (57 \%), в той час як група А виділила важливим більше роботи на ПК та навчання через Інтернет (52\%). 76 \% відповіли, що, на їх думку, інформаційні технології базуватимуться в майбутньому на більш широкому використанні Інтернету, 16 \% - на використанні баз даних, по 2,7 \% - на використанні мультимедіа і MS Office. 
Таблиця 1. Пропозиції студентів щодо покращення вивчення медичної інформатики та підготовки до роботи у первинній ланці охорони здоров'я

\begin{tabular}{|c|c|c|c|c|}
\hline $\begin{array}{c}\text { Деякі пропозиції щодо удосконалення освіти в галузі інформатики з } \\
\text { метою поліпшення роботи в первинній охороні здоров'я }\end{array}$ & \multicolumn{2}{|c|}{ Група А } & \multicolumn{2}{|c|}{ Група Б } \\
\hline Нічого & 16 & $30 \%$ & 5 & $24 \%$ \\
\hline Більше роботи на ПК & 9 & $17 \%$ & 3 & $15 \%$ \\
\hline Більше навчання через Інтернет & 10 & $19 \%$ & 5 & $24 \%$ \\
\hline Дистанційне навчання & 2 & $4 \%$ & 6 & $29 \%$ \\
\hline Більше роботи на ПК, більше навчання через Інтернет & 9 & $16 \%$ & 1 & $4 \%$ \\
\hline Більше навчання через Інтернет, дистанційне навчання & 4 & $7 \%$ & 0 & $0 \%$ \\
\hline $\begin{array}{l}\text { Більше роботи на ПК, більше навчання через Інтернет, дистанційне } \\
\text { навчання }\end{array}$ & 4 & $7 \%$ & 1 & $4 \%$ \\
\hline Всього & 54 & $100 \%$ & 21 & $100 \%$ \\
\hline
\end{tabular}

Середня оцінка студентів традиційної системи знань про комп'ютерні компоненти дорівнює 2,14 , використання Word - 2,82, 2,1 - Excel, 2,51 - Power Point, 3,64Internet, знання основних комп'ютерних понять -2,1, і в цілому знання IT $-2,55$. Середня оцінка студентів кредитно-модульної системи навчання знань складових комп'ютера $-2,87$, використання Word - 3,16, Excel-2,27, Power Point-2,84, Інтернет-3,81, основних IT-термінів-2,64, і 2,93 - знання в цілому.

Загалом, рівень викладання медичної інформатики на кафедрі було оцінено так: 4 \% респондентів оцінили його як погано, $13 \%$ - задовільно, 65 \% - добре, $17 \%$ - відмінно.

Удосконалення викладання медичної інформатики студенти-медики вбачають у забезпеченні навчальної дисципліни узгодженим з навчальною програмою підручником чи навчальним посібником; поглибленні практичних навиків з вивчення прикладних програм; набутті практичних навиків роботи з медичними інформаційними системами базового рівня та рівня лікувально-профілактичних установ, які запроваджені у систему охорони здоров'я України.

Таким чином, у результаті дослідження виявлено, що переважна більшість опитаних має доступ до комп'ютера та Інтернету, а також має відносно добрі практичні навики. Студенти кредитно-модульної системи значно частіше використовують комп'ютер, ніж студенти традиційної системи. Результати самооцінки також вищі у студентів, які навчаються за кредитномодульною системою. Суб'єктивно оцінюючи свої знання, студенти виділяють в якості кращих володіння навиками в застосуванні Інтернету та програми створення презентацій, значно гіршим $є$ володіння навиками у застосуванні електронних таблиць. Переважна більшість респондентів оволоділа навиками роботи на комп'ютерах самостійно, третина студентів, які навчаються за кредитно-модульною системою, - шляхом формальної освіти в школі, тоді як ніхто не брав участі в IT-програмах навчання. Більшість студентів вважає, що для удосконалення IT-освіти з метою поліпшення майбутньої роботи в первинній охороні здоров'я слід більше уваги приділяти вивченню Інтернету, баз даних та розвитку дистанційної освіти.

Порівнюючи результати цього дослідження 3 аналогічними дослідженнями, які були проведені на медичному факультеті Університету Сараєво у 2013/2014 н. р. та в Медичному університеті міста Рієка в Хорватії в 2005 році [5], видно, що за рівнем знань студентів, беручи до уваги їх суб'єктивну оцінку, є незначна різниця. Так, студенти Університету Сараєво оцінили свої знання в цілому на 3,00 бали (стара система навчання) та 3, 12 (Болонська система навчання). Однак загальні тенденції у рівні знань прикладних програм збігаються - краще знання Інтернет $(3,5$ та 3,78) i Power Point $(3,56$ та 3,68) проти нижчого рівня у знанні Excel $(2,3$ та 2,53) [4]. Студенти-медики у Хорватії оцінювали свої навички роботи з комп'ютером, знання комп'ютера, i важливість тих чи інших понять у медичній практиці 3 використанням шкали Lickert 3 п'ятьма ступенями. Середній бал навичок самооцінки становить 3,39 , знань - 2,69 та важливості IT-концепцій - 3,79 [5].

За даними аналогічного дослідження, проведеного у Данії в період з 1998 по 2002 рік зі студентамимедиками першого курсу, 71, 7 \% респондентів відповіли, що вони мають доступ до комп'ютера вдома. Цей відсоток істотно не змінився протягом періоду дослідження. До осені 2002 року приблизно 90 \% студентів регулярно використовували електронну пошту, $80 \%$ регулярно користувалися Інтернетом, а $60 \%$ мали доступ до Інтернету з дому. Досить постійне 
число студентів (3-7 \%) не хотіли б використовувати комп'ютери у своїх дослідженнях. Автори вважають, що ці результати вказують на необхідність поглиблення викладання основ IT, яка буде інтегрована в медичних дослідженнях, і ця потреба, напевно, не зникне в найближчому майбутньому [6].

Висновки. Результати проведеного дослідження показали, що студенти, які навчаються за кредитномодульною системою, суттєво відрізняються за рівнем знань, цілями використання та практичного застосування IT-знань від осіб, які навчалися за традиційною системою. Водночас, порівнюючи результати аналогічних досліджень, проведених в інших

\section{Список літератури}

1. Інформаційні технології в системі охорони здоров'я та медичної освіти / О. Ю. Майоров, В. М. Пономаренко, М. І. Хвістюк, В. В. Кальниш // Медична освіта. - 2002. № 2. - С. 60-68.

2. Качмар В. О. Стан розвитку медичної інформатики в Україні / В. О. Качмар // Медицина транспорту України. 2009. - №4. - С. 95-99.

3. Іщейкіна Ю. О. Проблеми підготовки з медичної інформатики студентів вищих навчальних закладів / Ю. О. Іщейкіна, О. В. Сілкова // Вісник проблем біології і медицини. 2011.- Т. 3 (89), вип. 3.- С. 128-129.

4. Information technologies in education of medical students at the University of Saraevo / I. Masik, E. Karcic, A. Hodzic, S. Mulic//Acta Inform. Med. -2014. - Vol. 22, № 4. - P. 228-231. країнах, слід відзначити дещо нижчий рівень знань IT, ніж у студентів-медиків Університету Сараєво в Боснії і Герцоговині, так само як і Медичного університету міста Рієка в Хорватії. Проблема удосконалення вивчення медичної інформатики залишається актуальною і одним із перспективних шляхів підвищення рівня знань студентів-медиків з цієї дисципліни є iї інтеграція з іншими медико-біологічними дисциплінами та тісна співпраця з практичною охороною здоров'я з метою впровадження у навчальний процес вивчення сучасних медичних інформаційних систем.

5. Samoprocjena informatickih vjestina, znanja i vaznosti pojmova iz medicinske informatike $\mathrm{u}$ studenata trece godine studija medicine u Hrvatskoj / T. Tabako, D. Zombori, H. Vrazic [et al.] // Medicinska Informatika 2005 / Kern, Josipa ; Hercigonja-Szekeres, Mira (ur.). - Zagreb : Hrvatsko drustvo za medicinsku informatiku , 2005. 17-22. [Електронний peсурс] Режим доступу: https://bib.irb.hr/prikazi$\mathrm{rad}$ ?rad=229713\&table=zbornik\&print=true.

6. Dorup J. Experience and Attitudes towards Information Technology among First-Year Medical Students in Denmark: Longitudinal Questionnaire Survey / J. Dorup // J. Med. Internet. Res. - 2004. - № 6 (1). - P. 10.

Отримано 12.12.14 